\title{
Ovine herpesvirus type 2-induced malignant catarrhal fever in a heifer
}

\section{Febre catarral maligna por herpesvírus ovino tipo 2 em uma novilha}

\author{
Selwyn Arlington Headley ${ }^{1 *}$; Júlio Augusto Naylor Lisbôa ${ }^{2}$; \\ Juliana Torres Tomazi Fritzen'; Gustavo Rodrigues Queiroz; \\ Alice Fernandes Alfieri'; Rodrigo Azambuja Machado de Oliveira5; \\ Ana Paula Frederico Rodrigues Loureiro Bracarense ${ }^{6}$; \\ Karina Keller Marques Costa Flaiban ${ }^{6}$; Amauri Alcindo Alfieri ${ }^{4}$
}

\begin{abstract}
The clinical, pathological, and molecular findings due to malignant catarrhal fever lesions induced by ovine herpesvirus type 2 (OvHV-2) are described in a 12-month-old, mixed-breed, heifer from northern Paraná, Brazil. The animal demonstrated clinical signs including manifestations of aggressive behavior, nystagmus, incoordination, decumbency, paddling movements, and death within 48 hours, after which was submitted for routine necropsy. Brain fragments were used in PCR assays for identification of infectious agents (OvHV-2; bovine herpesvirus-1 and -5; and Histophilus somni). Rabies was discarded in text done at the official state diagnostic laboratory. Significant pathological alterations include disseminated vasculitis with lymphoplasmacytic inflammatory infiltrate within the brain, kidneys, liver, and myocardium. PCR assay amplified the specific 422 base pair fragment of the OvHV-2 tegument protein gene from the brain; all other evaluations were negative. These findings confirm the participation of OvHV-2 in the etiopathogenesis of the disease observed in this mixed-breed heifer.
\end{abstract}

Kew words: Bovine disease, neuropathology, histopathology, molecular biology

\section{Resumo}

Os achados clínicos, patológicos e moleculares associados às lesões da febre catarral maligna por herpesvírus ovino 2 (OvHV-2) são descritos em uma novilha de 12 meses de idade, raça mista, da Região Norte do Estado Paraná, Brasil. O animal demonstrou comportamento agressivo, nistagmo, incoordenação motora, decúbito, movimentos de pedalagem e morte dentro de 48 horas, após a qual foi submetido à necropsia de rotina. Fragmentos do cérebro foram utilizados de PCR para a identificação de

\footnotetext{
${ }^{1}$ Prof. do Laboratório de Patologia Animal, Dept ${ }^{\mathrm{o}}$ de Medicina Veterinária Preventiva, Universidade Estadual de Londrina, UEL, Londrina, PR, Brasil. E-mail: selwyn.headley@uel.br

${ }^{2}$ Prof. Clínica de Ruminantes, Dept ${ }^{\circ}$ de Clínicas Veterinárias, Londrina, PR, Brasil. E-mail: janlisboa@uel.br

${ }^{3}$ Discentes, Programa de Pós-Graduação em Ciência Animal, UEL, Londrina, PR, Brasil. E-mail: jufritzen@uel.br; gustavorodriguesqueiroz11@gmail.com

${ }^{4}$ Profs. Laboratório de Virologia Animal, Dept ${ }^{0}$ de Medicina Veterinária Preventiva, UEL, Londrina, PR, Brasil. E-mail: aalfieri@ uel.br; alfieri@uel.br

${ }^{5}$ Discente do Programa de Pós-Graduação em Ciência Animal, UEL, Londrina, PR, Brasil. E-mail: roliveira.azambuja@gmail. com

${ }^{6}$ Prof $^{\text {as }}$. do Laboratório de Patologia Animal, Dept ${ }^{\circ}$ de Medicina Veterinária Preventiva, UEL, Londrina, PR, Brasil. E-mail: anapaula@uel.br; kkflaiban@uel.br

* Author for correspondence
} 
agentes infecciosos (OvHV-2; herpesvírus bovino-1 e -5 e Histophilus somni). A raiva foi descartada por exame realizado em laboratório oficial de diagnóstico do estado. Alterações patológicas significativas incluíram vasculite disseminada com infiltrado inflamatório linfoplasmocitário no cérebro, rins, fígado e miocárdio. A PCR amplificou específico do gene da proteína do tegumento do OvHV-2 a partir de amostras do cérebro; todas as outras avaliações foram negativas. Estes resultados confirmam a participação de OvHV-2 na etiopatogenia da doença observada nesta novilha.

Palavras-chave: Doença bovina, neuropatologia, histopatologia, biologia molecular

Malignant catarrhal fever (MCF) is a fatal disease that affects domestic cattle, wild ruminants, and occasionally pigs, which is caused by cross species infection of members of the genus Rhadinovirus, subfamily Gammaherpesvirinae (MACLACHLAN; DUBOVI, 2011). Two distinct clinical manifestations of MCF are recognized: one is caused by Alcelaphineherpesvirus type 1 (AlHV1), which uses wildebeest (Connochaetes gnu and C. taurinus) as a carrier, and occurs predominantly within Africa; the other manifestation is induced by ovine herpesvirus type 2 (OvHV-2), occurs outside of the African continent, affects cattle, bison, and deer, but sheep are the recognized carriers (BROWN et al., 2007; ZACHARY, 2012). Consequently, these manifestations are referred to as wildebeest associated (WA-MCF) and sheep-associated (SA$\mathrm{MCF}$ ) malignant catarrhal fever, respectively (BROWN; BAKER; BAKER, 2007).

The clinical and pathological features associated with MCF in cattle have been described in all regions of Brazil (GARMATZ et al., 2004; LEMOS et al., 2005; HEADLEY et al., 2012). However, most of these studies have been based exclusively on the characteristic histopathological features of SA-MCF induced lesions in cattle (BROWN; BAKER; BAKER, 2007), with few investigations combining the specificity of Polymerase Chain Reaction (PCR) assays with pathological alterations (GARMATZ et al., 2004; MENDONÇA et al., 2008). Nevertheless, PCR assays with sequencing was used to characterize the agent in tissues from cattle originated from Rio Grande do Norte (HEADLEY et al., 2012), and buffalos (COSTA et al., 2009a) and one horse (COSTA et al., 2009b) from Minas Gerais with typical histopathological lesions that are consistent with those induced by OvHV-2.

Since the early description of an outbreak of SAMCF within the state of Paraná, based exclusively on histopathological findings (BAPTISTA; GUIDI, 1988), there has been no additional notification of this disease. Consequently, this report presents the clinical, pathological, and molecular findings associated with OvHV-2 induced meningoencephalitis in a cow from northern Paraná.

During early March 2012, a 12-months-old, mixed-breed heifer that was maintained in a farm located in the municipality of Sabáudia, northern Paraná, Brazil, died within two days after the onset of clinical manifestations. Initially, the heifer was apathetic, anorexic, and became separated from the herd, demonstrating mild incoordination. On the second day the animal demonstrated aggressive behavior, nystagmus, diarrhea, hypermetria, fever, and lateral decumbency with paddling movements; lymphadenopathy and nasal and ocular secretions were not observed. The heifer died spontaneously 48 hours after the onset of clinical signs. This heifer was maintained on a farm that contained 130 animals (including dairy and beef cattle and goats, but without sheep), but was acquired from another herd 60 days prior to the demonstration of initial clinical manifestations. All cattle were routinely vaccinated against foot-andmouth disease, brucellosis, and clostridiosis.

Blood and cerebrospinal fluid (CSF) samples were collected before death and complete blood cell counts and CSF analyses were performed using routine methods. Necropsy was performed soon after death and selected tissue sections (brain, liver, intestine, kidney, lungs, and spleen) were routinely processed for histopathological evaluation. Selected brain fragments 
(thalamus, cerebrum, cerebellum, brainstem, and trigeminal nerve ganglia) were aseptically collected during necropsy and maintained at $-20^{\circ} \mathrm{C}$ until used for the molecular identification of common infectious agents associated with neurological manifestations in cattle. Brain fragments collected for rabies virus identification were maintained at 4 to $8{ }^{\circ} \mathrm{C}$.

DNA extracted from brain fragments (BOOM et al., 1990) was used in PCR assays designed to amplify specific amplicons of the OvHV-2 tegument protein gene (BAXTER et al., 1993), glycoprotein $\mathrm{C}$ gene of bovine herpesvirus type 1 (BoHV-1) and BoHV-5 (CLAUS et al., 2005) and the 16s rRNA gene of Histophilus somni (ANGEN et al., 1998). Positive controls consisted of DNA from other cases: OvHV-2 (HEADLEY et al., 2012); H. somni (HEADLEY et al., 2013); prototype strains of BoHV-1 (Los Angeles) and -5 (AA-Par) amplified in Madin-Darby bovine kidney cells (CLAUS et al., 2005). Nuclease-free water (Invitrogen Corporation, Carlsbad, CA, USA) was used as negative controls in all PCR assays. All PCR products were separated by electrophoresis in $2 \%$ agarose gels, stained with ethidium bromide, and examined under ultraviolet light. Direct immunofluorescence was performed for the identification of rabies virus in brain samples sent to an Official Diagnostic Laboratory (Centro de Diagnóstico Marcos Enrietti; Curitiba, PR, Brazil).

The amplified PCR products were then purified (illustra GFX PCR DNA and Gel Band Purification Kit; GE Healthcare, Buckinghamshire, UK) and submitted for direct sequencing with sense and anti-sense primers. The partial nucleotide sequences (Accession $\mathrm{N}^{\circ} \mathrm{KC123170)}$ were initially compared by the BLAST (http://www.ncbi.nlm. nih.gov/BLAST) program with similar sequences deposited in GenBank. Phylogenetic trees and sequence alignments were then created by using MEGA 5.10 (TAMURA et al., 2011), constructed by the Neighbor-Joining method, based on 1,000 bootstrapped data sets; distances values were calculated by using the Kimura 2 parameter model. The nucleotide sequences used for phylogenetic analyses during this study are given in Figure 1.

Figure 1. The phylogenetic relationship of nucleotide sequences of selected strains of the ovine herpesvirus type 2 tegument protein gene generated by MEGA 5. The GenBank accession numbers, the country of origin, and the associated specie of the sequences used are given. The sequences derived from this study are highlighted within the box. Murine herpervirus was used as the out-group. Legend: MG, Minas Gerais; PR, Paraná; RN, Rio Grande do Norte.

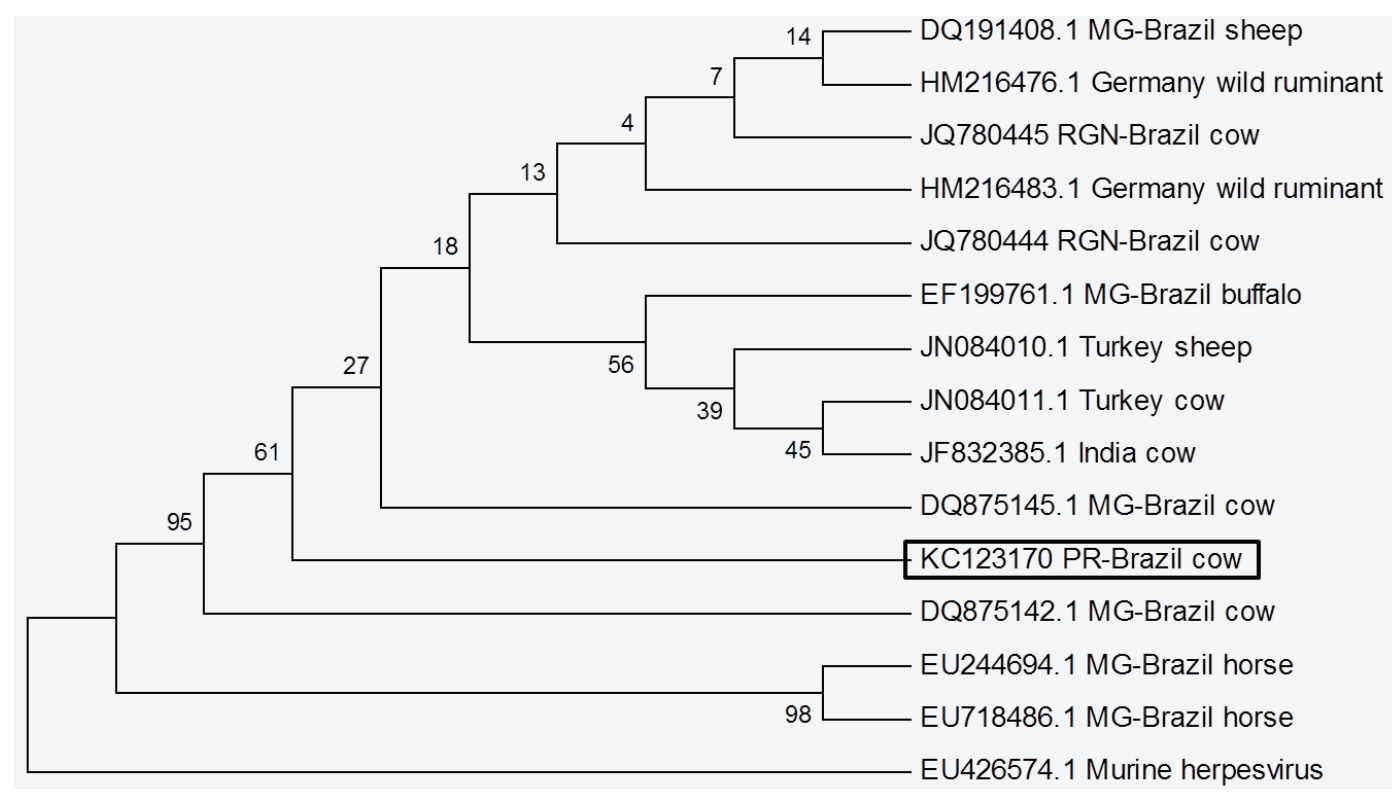

Source: Elaboration of the authors. 
CSF alterations were typical and indicative of inflammatory brain disease. Elevated protein concentration $(180 \mathrm{mg} / \mathrm{dL})$ was accompanied by mononuclear pleocytosis (38 nucleated cells $/ \mathrm{mm}^{3}$ ) with $88 \%$ of lymphocytes, $6 \%$ of monocytes, and $6 \%$ of neutrophils. CSF was colorless and slightly turbid.

Gross alterations included congestion of vessels of the meninges, pulmonary hemorrhage, enlarged mesenteric lymph nodes, cortical renal congestion, foci of hemorrhage and congestion within the intestinal tract, and abomasal ulcerations. Histopathological evaluation revealed widespread vasculitis with lymphoplasmacytic accumulations within several tissues, but these alterations were more severe within the brain. There was necrotizing vasculitis with lymphoplasmacytic meningoencephalitis at the brainstem (Figure 2A), thalamus (Figure 2B), cerebrum, and cerebellum (Fig. 2C), and lymphoplasmacytic inflammatory accumulations and vasculitis within the liver (Figure 2D), kidneys, and heart.

Positive amplicons were amplified from the PCR assay designed to identify the 422 base pairs of the OvHV-2 tegument protein gene; all other assays produced negative results and rabies virus was not detected. Additionally, OvHV-2 DNA was only amplified from the brainstem. BLAST analyses demonstrated that the nucleotide sequences derived from the brainstem were $99-96 \%$ similar to other sequences deposited in GenBank. Phylogenetic analyses demonstrated that these sequences clustered with similar sequences derived from wild and domestic ruminants from Brazil and other countries, but were distant from those obtained from horses originated from Minas Gerais/Brazil (Figure 1).

Figure 2. Histopathological demonstrations of ovine herpesvirus type 2 -induced lesions in a mixed-breed heifer with malignant catarrhal fever. There is vasculitis at the meninges of the brainstem (A), and vasculitis with lymphoplasmacytic inflammatory infiltrate at the thalamus (B), cerebellum (C), and the liver. (Hematoxylin and Eosin stain; Bar, A and D, $30 \mu \mathrm{m}$; B-C, $100 \mu \mathrm{m}$.)

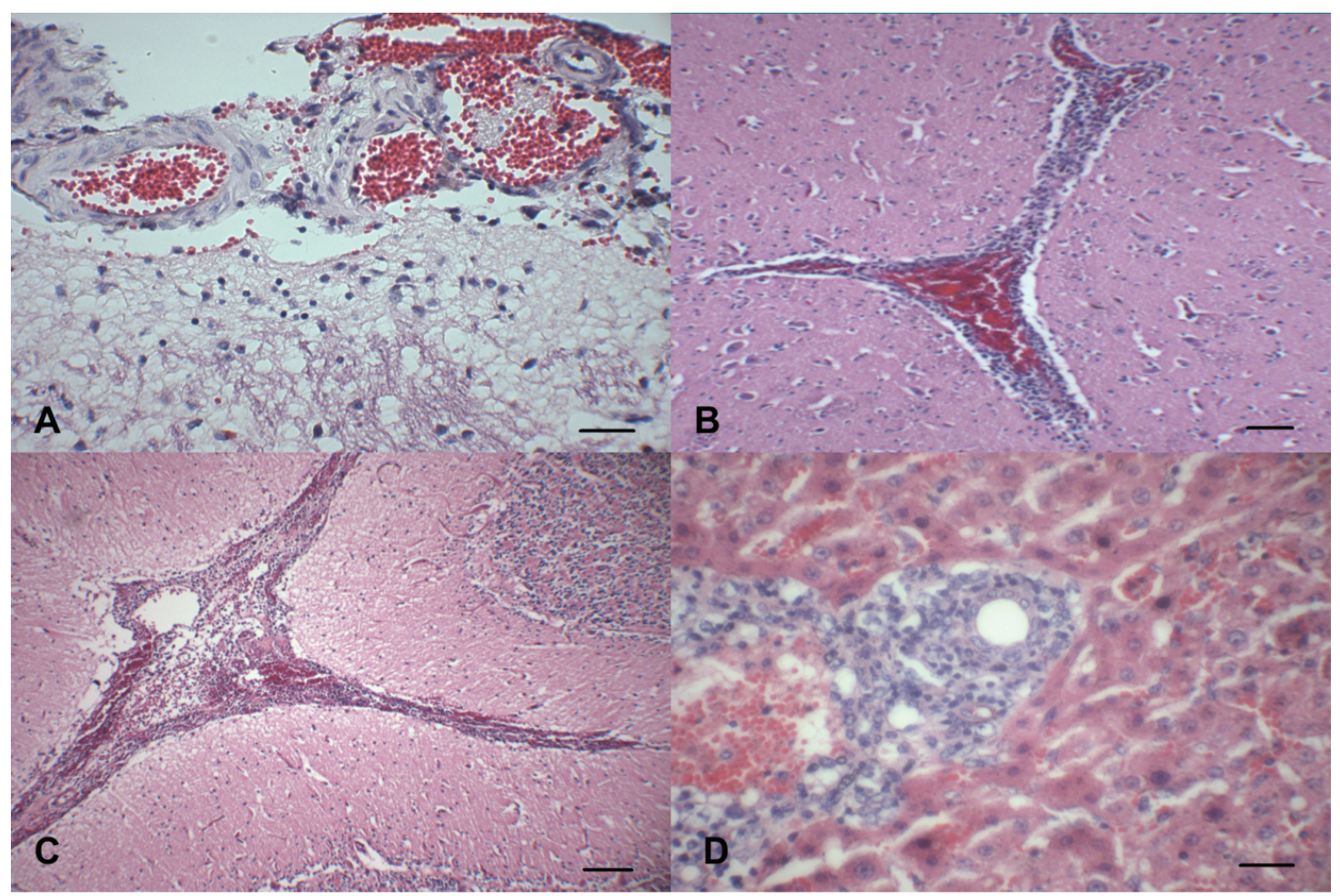

Source: Elaboration of the authors. 
The clinical manifestations associated with the histopathological alterations observed in this heifer are consistent with those seen in cases of SA-MCF (BROWN; BAKER; BAKER, 2007; ZACHARY, 2012). However, nasal and ocular secretions and lymphadenopathy frequently described in MCF were not observed in the present case. Nevertheless, studies done in Brazil have described manifestations of MCF in cattle (GARMATZ et al., 2004; LEMOS et al., 2005; MENDONÇA et al., 2008; HEADLEY et al., 2012) and buffalos (COSTA et al., 2009a) from different geographical regions. The identification of the OvHV-2 DNA from the brainstem using specific primers designed to amplify this gene (BAXTER et al., 1993) confirmed the participation of this virus in the etiopathogenesis of the disease herein described. Other investigations done in Brazil, using molecular biology have also identified this virus in tissues from cattle (HEADLEY et al., 2012), buffalos (COSTA et al., 2009a), and a horse (COSTA et al., $2009 b$ ) by sequencing of the tegument protein gene. The negative results obtained by the $H$. somni, BoHV-1 and -5 PCR assays as well as the negative identification of rabies virus suggest that only OvHV2 was associated with the clinical manifestations and lesions observed in this heifer. Additionally, Listeria monocytogenes and other bacterial species were also excluded as possible etiological agents due to the absence of characteristic histopathological findings within the brainstem and brain, respectively.

The results of phylogenetic analyses have confirmed that the sequences derived from this study clustered with similar sequences obtained from wild and domestic ruminants deposited in GenBank from various geographical locations, but were distant from those derived from horses; similar results have been described (HEADLEY et al., 2012). These results suggest that all cases of SA-MCF worldwide are induced by OvHV-2 in ruminants, and are probably derived from the same linage, while those from horses might be distantly related.

The characterization of SA-MCF in this animal from the state of Paraná adds to the only description
(BAPTISTA; GUIDI, 1988) of this important disease within this geographical region of Brazil. In the first description of MCF within this state (BAPTISTA; GUIDI, 1988), 25\% (59/237) of cows from Ribeirão do Pinhal, located approximately 120 $\mathrm{km}$ from Londrina, were affected, but 95\% (56/59) of these died; morbidity was reduced $(0.8 \% ; 1 / 130)$ in this study. Additionally, morbidity, varying between $1.8-20 \%$, with elevated lethality (83.3$100 \%$ ) associated with outbreaks of MCF have been described in Rio Grande do Norte (HEADLEY et al., 2012), Rio Grande do Sul (RECH et al., 2005); and Mato Grosso (MENDONÇA et al., 2008). These results demonstrated that variations in morbidity but elevated lethality is frequently associated with outbreaks of this disease, an epidemiological feature that is characteristic of MCF (BROWN; BAKER; BAKER, 2007).

In conclusion, PCR assay successfully amplified the desired amplicon of the OvHV-2 tegument protein gene from the brain of a heifer that had histopathological alterations consistent with those observed in MCF of ruminants. This case adds to the few studies done in Brazil that have fully characterized this pathogen by molecular biology.

\section{Acknowledgements}

Selwyn Arlington Headley, Júlio A. N. Lisbôa, Alice F. Alfieri, Ana Paula F. R. L. Bracarense, and Amauri A. Alfieri are recipients of the National Council for Scientific and Technological Development (CNPq, Brazil) fellowships. This study was partially funded by a joint $\mathrm{CNPq}$ /Ministry of Agriculture, Livestock, and Supply (MAPA) grant (Protocol \#578645/2008-4).

\section{References}

ANGEN, O.; AHRENS, P.; TEGTMEIER, C. Development of a PCR test for identification of Haemophilus somnus in pure and mixed cultures. Veterinary Microbiology, Amsterdam, v. 63, n. 1, p. 3948, 1998. 
BAPTISTA, F. Q.; GUIDI, P. C. Febre catarral maligna no estado do Paraná. A Hora Veterinária, Porto Alegre, v. 45, p. 33-37, 1988

BAXTER, S. I.; POW, I.; BRIDGEN, A.; REID, H. W. PCR detection of the sheep-associated agent of malignant catarrhal fever. Archives of Virology, New York, v. 132, n. 1-2, p. 145-159, 1993.

BOOM, R.; SOL, C. J.; SALIMANS, M. M.; JANSEN, C. L.; WERTHEIM-VAN DILLEN, P. M.; VAN DER NOORDAA, J. Rapid and simple method for purification of nucleic acids. Journal of Clinical Microbiology, Washington, v. 28, n. 3, p. 495-503, 1990.

BROWN, C. B.; BAKER, D. C.; BAKER, I. K. Alimentary system. In: MAXIE, M. G. (Ed.). Jubb, kennedy, and palmer's pathology of domestic animals. $5^{\text {th }}$ ed. St. Loius, Philadelphia: Saunders/Elsevier, 2007. v. 2, cap. 1, p. 152-159.

CLAUS, M. P.; ALFIERI, A. F.; FOLGUERASFLATSCHART, A. V.; WOSIACKI, S. R.; MEDICI, K. C.; ALFIERI, A. A. Rapid detection and differentiation of bovine herpesvirus 1 and 5 glycoprotein $\mathrm{C}$ gene in clinical specimens by multiplex-PCR. Journal of Virological Methods, Amsterdam, v. 128, n. 1-2, p. 183-188, 200.

COSTA, E. A.; BASTIANETTO, E.; VASCONCELOS, A. C.; BOMFIM, M. R. Q.; FONSECA, F. G. D.; GOMES, A. D.; LEITE, R. C.; RESENDE, M. An outbreak of malignant catarrhal fever in Murrah buffaloes in Minas Gerais, Brazil. Pesquisa Veterinária Brasileira, Rio de Janeiro, v. 29, n. 5, p. 395-400, 200a.

COSTA, E. A.; BOMFIM, M. R.; FONSECA, F. G.; DRUMOND, B. P.; COELHO, F. M.; VASCONCELOS, A. C.; FURTINI, R.; PAIXAO, T. A.; TSOLIS, R. M.; SANTOS, R. L.; RESENDE, M. Ovine herpesvirus 2 infection in Foal, Brazil. Emerging Infectious Diseases, Atlanta, v. 15, n. 5, p. 844-845, 209b.

GARMATZ, S. L.; IRIGOYEN, L. F.; RECH, R. R.; BROWN, C. C.; ZHANG, J.; BARROS, C. S. L. Febre catarral maligna em bovinos no Rio Grande do Sul: transmissão experimental para bovinos e caracterização do agente etiológico. Pesquisa Veterinária Brasileira, Rio de Janeiro, v. 24, n. 2, p. 93-103, 004.
HEADLEY, S. A.; OLIVEIRA, V. H.; FIGUEIRA, G. F.; BRONKHORST, D. E.; ALFIERI, A. F.; OKANO, W.; ALFIERI, A. A. Histophilus somni-induced infections in cattle from southern Brazil. Tropical Animal Health and Production, London, v. 45, p. 1579-1588, 2013.

HEADLEY, S. A.; SOUSA, I. K. F.; MINERVINO, A. H. H.; BARROS, I. O.; BARRÊTO JÚNIOR, R. A.; ALFIERI, A. F.; ORTOLANI, E. L.; ALFIERI, A. A. Molecular confirmation of ovine herpesvirus 2-induced malignant catarrhal fever lesions in cattle from Rio Grande do Norte, Brazil. Pesquisa Veterinária Brasileira, Rio de Janeiro, v. 32, n. 12, p. 1213-1218 2012.

LEMOS, R. A. A. D.; RECH, R. R.; GUIMARÃES, E. B.; KADRI, A.; DUTRA, I. D. S. Febre catarral maligna em bovinos do Mato Grosso do Sul e de São Paulo. Ciência Rural, Santa Maria, v. 35, n. 4, p. 932-93, 2005.

MACLACHLAN, N. J.; DUBOVI, E. J. Fenner's veterinary virology. $4^{\text {th }}$ ed. San Diego, California: Academic Press, 211. 507.

MENDONÇA, F. S.; DÓRIA, R. G. S.; SCHEIN, F. B.; FREITAS, S. H.; NAKAZATO, L.; BOABAID, F. M.; PAULA, D. A. J.; DUTRA, V.; COLODEL, E. M. Febre catarral maligna em bovinos no Estado de Mato Grosso. Pesquisa Veterinária Brasileira, Rio de Janeiro, v. 28, n. 3, p. 155-60, 2008.

RECH, R. R.; SCHILD, A. L.; DRIEMEIER, D.; GARMATZ, S. L.; OLIVEIRA, F. N.; RIET-CORREA, F.; BARROS, C. S. L. Febre catarral maligna em bovinos no Rio Grande do Sul: epidemiologia, sinais clínicos e patologia. Pesquisa Veterinária Brasileira, Rio de Janeiro, v. 25, n. 2, p. 97105, 2005.

TAMURA, K.; PETERSON, D.; PETERSON, N.; STECHER, G.; NEI, M.; KUMAR, S. MEGA5: molecular evolutionary genetics analysis using maximum likelihood, evolutionary distance, and maximum parsimony methods. Molecular Biology and Evolution, Chicago, v. 28, n. 10, p. $27312739,2011$.

ZACHARY, J. F. Bovine malignant catarrhal fever. In: ZACHARY, J. F.; MCGAVIN, M. D. (Ed.). Pathologic basis of veterinary disease. $5^{\text {th }}$ ed. St Louis, Missouri: Elsevier/Mosby, 2012. cap. 4, p. 219-219. 